\title{
30. CENOZOIC EVOLUTION AND SIGNIFICANCE OF CLAY ASSOCIATIONS IN THE NEW ZEALAND REGION OF THE SOUTH PACIFIC, DEEP SEA DRILLING PROJECT, LEG $90^{1}$
}

\author{
Christian Robert, Faculté des Sciences de Luminy, \\ Rüdiger Stein, Geologisch-Paläontologisches Institut und Museum der Universität Kiel \\ and \\ Monique Acquaviva, Faculté des Sciences de Luminy²
}

\begin{abstract}
Clay minerals, flux rates, and the size distribution of terrigenous matter in DSDP Sites 592, 593, and 594 have been used to reconstruct continental and marine paleoenvironments in the New Zealand sector of the southwest Pacific. Five stages are recognized from late Eocene to Pleistocene times.

1. At the Eocene-Oligocene boundary, illite and mixed-layer clays marked a period of tectonic extension related to graben formation and volcanic activity.

2. During the Oligocene, smectites formed abundantly in plains and perimarine lagoons which developed during subsidence-induced peneplanation of the relief.

3. During the early Miocene, greater abundances of chlorite, illite, and irregular mixed-layer clays, and the appearance of kaolinite were due to an increase in the relief of New Zealand that followed the inception of a compressive regime; in the Tasman Sea, part of the detrital supply (smectites) was derived from the north and was deposited by southward-flowing currents.

4. From middle Miocene to early late Miocene time, abundant chlorite, illite, mixed-layer clays, and kaolinite, and the appearance of stilpnomelane marked an important tectonic event in New Zealand which increased the detrital supply to the whole South Tasman Sea; on the Chatham Rise, abundant smectites from the north diluted the detrital supply influenced by the tectonic activity in New Zealand.

5. From early late Miocene to Pleistocene time, abundant chlorite, illite, mixed-layer clays, kaolinite, and stilpnomelane were eroded from New Zealand, where the Kaikoura orogeny increased the relief, and deposited in the South Tasman Sea; during the late Pliocene, both grain size and amounts of clay particles eroded from New Zealand increased, related to reinforced bottom-current activity on the Lord Howe Rise; on the Chatham Rise, increased detrital components from the Southern Alps (chlorite, illite, mixed-layer clays, stilpnomelane) were supplied by northwardflowing currents.
\end{abstract}

\section{INTRODUCTION}

During Leg 90 of the Deep Sea Drilling Project in the southwest Pacific, holes were drilled at three sites at depths coinciding with upper water masses, close to New Zealand, in an area marked by the convergence of the Indo-Australian and Pacific plates. As shown in Figure 1, DSDP holes were drilled on the southern part of the Lord Howe Rise (Site 592), on the Challenger Plateau (Site 593), and on the Chatham Rise (Site 594). Basic data about the sites is given in Table 1 .

The purpose of this study is to determine the effect of structural evolution, climatic changes, and current interactions on sedimentation, using variations in clay minerals, flux rates, and size distribution of terrigenous matter. Similar approaches have previously been used to determine the paleoenvironmental evolution of the Atlantic Ocean (Chamley, 1979; Robert, 1982; Stein, 1984).

\footnotetext{
${ }^{1}$ Kennett, J. P., von der Borch, C. C., et al., Init. Repts. DSDP, 90: Washington (U.S Govt, Printing Office).

2 Addresses: (Robert, Acquaviva) Géologie Marine, UA CNRS 41, Faculté des Sciences de Luminy, Case 901, 13288 Marseille Cedex 9, France; (Stein, present address) Institute of Petroleum and Organic Geochemistry (ICH-5), KFA Jülich, P.O. Box 1913, 5170 Jülich, Federal Republic of Germany.
}

\section{METHODS}

\section{Clay Mineralogy}

In each sample, the $<63 \mu \mathrm{m}$ size fraction was leached in $0.2 \mathrm{~N}$ hydrochloric acid. The excess acid was removed by repeated centrifugations followed by homogenization. The $<2 \mu \mathrm{m}$ size fraction was separated by decantation (settling time based on Stokes' Law), and oriented aggregates were made on glass slides. Three X-ray diffractograms were made: (1) untreated sample; (2) glycolated sample; (3) sample heated for $2 \mathrm{hr}$. at $490^{\circ} \mathrm{C}$. A C.G.R. Thêta 60 diffractometer (copper $\mathrm{K} \alpha$ radiation focused by a quartz curved monochromator) was used at scan speeds of $1^{\circ} 2 \theta / \mathrm{min}$. A receiving slit of $1.25 \mathrm{~mm}$ allowed a more precise resolution of poorly crystallized minerals.

Semiquantitative evaluations were based on the peak heights and areas. Data are given in percentages, the relative error being $\pm 5 \%$. The relative abundances of smectites versus illite ( $\mathrm{S} / \mathrm{I}$ index) and of kaolinite versus illite $(\mathrm{K} / 1$ index) were obtained from the ratios of the

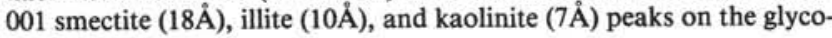
lated sample.

Some samples were selected for transmission electron microscopy analysis. The $<8 \mu \mathrm{m}$ size fraction was separated by decantation, and the particles were scattered into a solution of tert-butylamin. A drop of the suspension was then deposited on a copper grid, which had been previously covered by a membrane of collodion. The samples were analyzed using a Philips EM 300 microscope.

\section{Grain Size and Flux Rates of Terrigenous Matter}

The carbonate content was determined by infrared absorption of $\mathrm{CO}_{2}$ released by phosphoric acid treatment. The $<63 \mu \mathrm{m}$ size fraction was treated successively with hydrogen peroxide and acetic acid in or- 


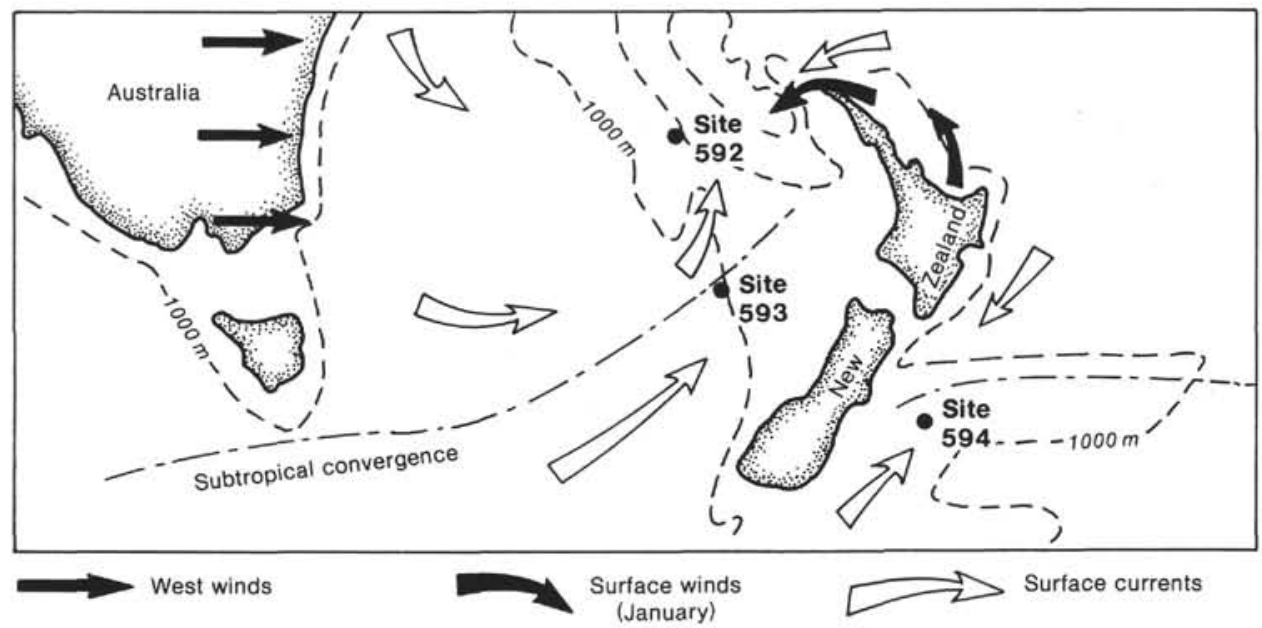

Figure 1. Location of Leg 90 Sites 592, 593, and 594. $1000 \mathrm{~m}$ isobath shown.

Table 1. Site data for Sites 592, 593, and 594 .

\begin{tabular}{lllccl}
\hline Site & Latitude (S) & Longitude (E) & $\begin{array}{c}\text { Water } \\
\text { depth } \\
(\mathrm{m})\end{array}$ & $\begin{array}{c}\text { Penetration } \\
(\mathrm{m})\end{array}$ & $\begin{array}{c}\text { Oldest } \\
\text { sediment } \\
\text { recovered }\end{array}$ \\
\hline 592 & $36^{\circ} 28.40^{\prime}$ & $165^{\circ} 26.53^{\prime}$ & 1098 & 388.5 & late Eocene \\
593 & $40^{\circ} 30.47^{\prime}$ & $167^{\circ} 40.47^{\prime}$ & 1068 & 571.5 & late Eocene \\
594 & $45^{\circ} 31.41^{\prime}$ & $174^{\circ} 56.88^{\prime}$ & 1204 & 639.5 & middle Miocene \\
\hline
\end{tabular}

der to remove both organic matter and calcium carbonate, respectively. The carbonate-free fraction was separated into $>6 \mu \mathrm{m}$ and $<6 \mu \mathrm{m}$ size fractions according to the method of Atterberg. The composition of the $>6 \mu \mathrm{m}$ size fraction was analyzed using a microscope, and its grain size was measured with a Coulter counter. The mass accumulation rates were calculated according to the method of Thiede et al. (1982), using the shipboard porosity and wet-bulk density data of Morin (site chapters, this volume). Details of the methodology are given by Stein and Robert (this volume).

\section{ORIGIN AND SIGNIFICANCE OF THE PARTICLES}

The sediments consist mainly of nannofossil to foraminifer-bearing nannofossil oozes and chalks. At Site 594 (Chatham Rise), foraminifer and clay-bearing nannofossil oozes, clayey silty nannofossil oozes, nannofossil silty clays and silty clays, sometimes associated with diatomaceous sponge spicule silts, are present in late Miocene to Pleistocene sediments. At Site 593 on the Challenger Plateau, volcanogenic turbidites are surrounded by upper Eocene and lower Oligocene sediments (site chapters, this volume).

\section{General Results}

Clay minerals include smectites, illite, chlorite, irregular mixed-layer clays (illite-smectite and chlorite-smectite), kaolinite, and stilpnomelane (Figs. 2-5). Abundant illite and irregular mixed-layer clays (up to $40 \%$ ) were deposited on the southern Lord Howe Rise (Site 592) during the late Eocene and the early Oligocene, when dominant smectites (up to 95\%) were deposited on the Challenger Plateau (Site 593). During the Neogene, chlorite, illite, irregular mixed-layer clays, and sometimes kaolinite increased at all sites, but in a different way. On the southern Lord Howe Rise (Site 592), smectites remained dominant (up to $100 \%$ ) during the early Miocene, decreasing, however, in the middle Miocene. Minimum values of smectites $(<25 \%)$, also indicated by extremely low S/I ratios, occurred during the last $4 \mathrm{~m} . \mathrm{y}$. This change in the sediment record of Site 592 coincided with a distinct coarsening of both bulk sediment and terrigenous sediment fractions, and a distinct decrease in accumulation rates of terrigenous matter. On the Challenger Plateau (Site 593), chlorite, illite, irregular mixedlayer clays, and kaolinite increased as early as the early Miocene. On the Chatham Rise (Site 594), smectites were abundant until the late Pliocene and then decreased, being replaced by dominant chlorite, illite, and irregular mixed-layer clays (Figs. 2, 4, 5).

Electron micrographs show very rare palygorskite-like fibers at Sites 592 and 593 (Plate 1). During the late Eocene, while volcanogenic turbidites were deposited at Site 593 , the clay fraction temporarily consisted of up to $90 \%$ smectites on the southern Lord Howe Rise (Site 592). At this level, the clay particles consist mainly of thick laths and associated globular packs of fine laths (Plate 1). The latter are also present in the sedimentary record at levels where volcanic glass is present, as well as in the vicinity of greenish gray laminae attributed to the presence of devitrified volcanic ash. This observation can be extended to the other sites of the Lord Howe Rise (Stein and Robert, this volume). In the Leg 90 sediments marked by abundant smectites (up to $95 \%$ of the clay fraction), there is a general occurrence of very fine, transparent, and apparently fragile laths (Plate 2). These laths are more abundant in Eocene to Miocene sediments, and become sparse in Pliocene and Quaternary sediments. The fine laths scattered in the background of the micrographs are often associated in geometrical figures with $60^{\circ}$ angles (Plate 2). These laths are also present at the periphery of fleecy packs and large particles (Plate 2). They are sometimes arranged in urchinlike groups (Plate 2). Lastly, biosiliceous fragments occasionally show traces of dissolution, and small tufts of fibers are present at the periphery and within the frustules (Plate 2). 


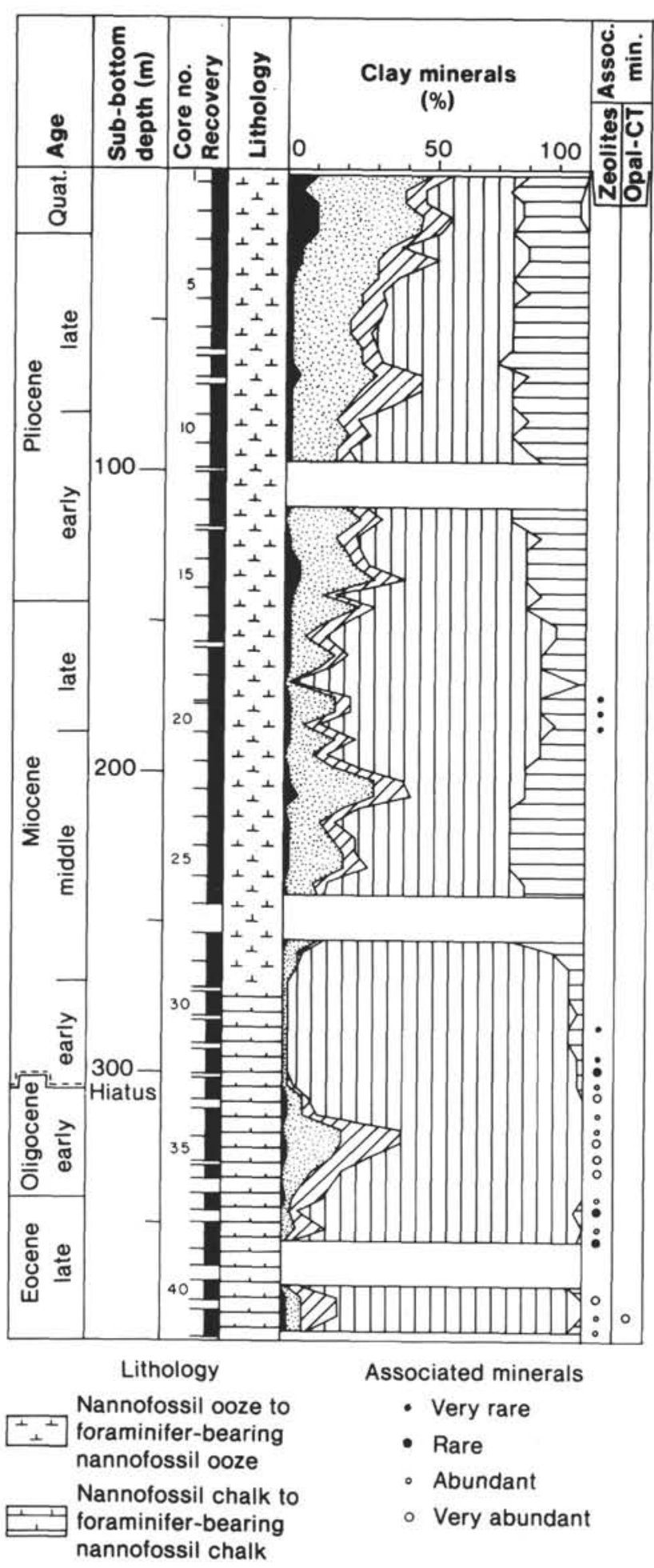

Clay mineralogy
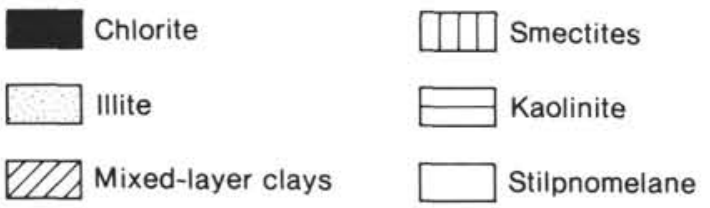

Figure 2. Site 592 results.

\section{Early Diagenesis}

Generally, smectites appear in the soil on land, in the form of fleecy particles (Chamley and Bonnot-Courtois, 1981; Robert, 1982). In the Leg 90 sediments characterized by abundant smectites, electron micrographs often show that this morphological type is scarce. Instead, fine laths are present; their fineness and apparent fragility, as well as their ubiquity, suggest that they were formed in situ. Similar morphological types of smectites were described in the North Atlantic during Aptian-Albian and early Cenozoic times (Holtzapffel et al., in press). These studies show that fine laths of smectites originated during in situ recrystallization of smectites, within the interstitial sedimentary environment, without significant chemical or mineralogical change. In the dominantly terrigenous environments of the Atlantic, the formation of fine-lathed smectites was favored by low sedimentation rates. In the southwest Pacific, sedimentation rates are high, but the terrigenous component of the sediment is highly diluted by the biogenic elements. Possibly recrystallization of smectites is favored when terrigenous supply is weak.

In biosiliceous fragments, tufts of fibers are probably small particles of smectites, formed in these microenvironments from the silica of the skeletons. Similar processes of smectite formation were described by Hoffert (1980) in the central Pacific. In the southwest Pacific, the scarcity of siliceous microfossils excludes this mechanism as a major contributor to smectite genesis.

\section{Volcanic Influence}

The thick laths and globular packs of fine laths in the sediments of the south Tasman Sea are generally associated with volcanic elements. Similar thick laths, sometimes associated with packs of laths, were observed near the Daito Ridge in the Philippine Sea (Chamley, 1980), and on the Walvis Ridge in the South Atlantic (Chamley et al., 1984). In both of these regions, smectites were chiefly formed during subaerial alteration processes in volcanic products. At Site 592, thick laths of smectites appear contemporaneously with the volcanogenic turbidites which were emplaced at Site 593. During the late Eocene, volcanic events were common in the southwest Pacific (Site 593 site chapter, this volume). Volcanogenic smectites observed on the southern Lord Howe Rise (Site 592) and on the Challenger Plateau (Site 593) were probably derived from erosion of altered volcanic material, transported by winds and currents.

\section{Detrital Supply}

Chlorite, illite, and irregular mixed-layer clays, which are associated with stilpnomelane, are abundant at all sites, especially from the late Miocene to the Pleistocene. Chlorite and illite are partly derived from the erosion of crystalline and metamorphic rocks. During alteration, chlorite, illite, and irregular mixed-layer clays are formed preferentially under humid, temperate climatic conditions, and their formation is also favored by continental mountain relief with active tectonism and erosion (Millot, 1964; Chamley, 1979). These conditions 


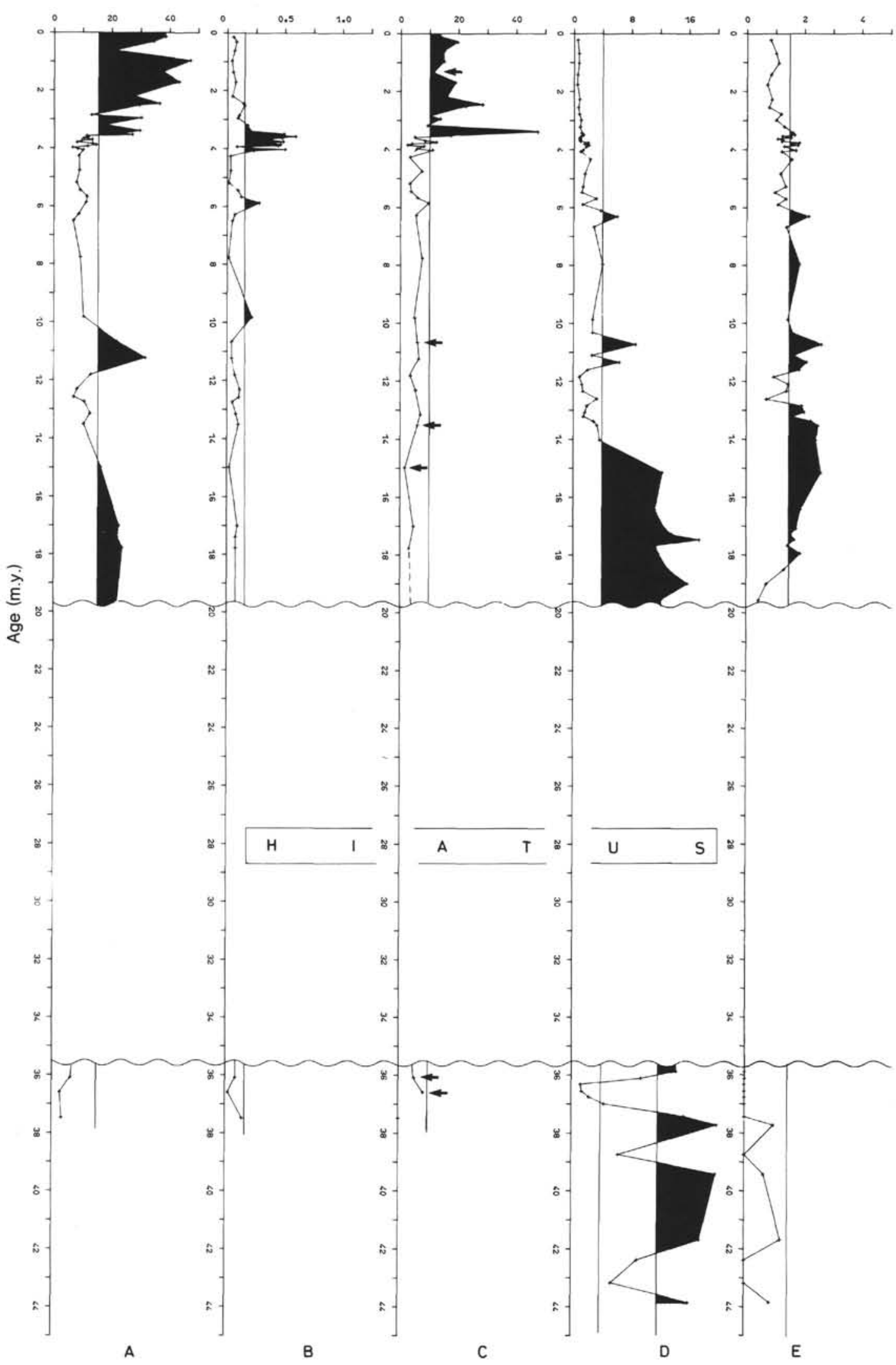

Figure 3. Site 592 results. A. Percentages of the $<63 \mu \mathrm{m}$ size fraction of the sediment. B. Accumulation rate of the carbonate-free fraction in $\mathrm{g} /\left(\mathrm{cm}^{2} \times 10^{3} \mathrm{yr}\right.$.). C. Percentages of the terrigenous sediment fraction $>6 \mu \mathrm{m}$ of the carbonate-free sediment fraction. Arrows indicate samples with significant amounts of volcanic glass. D. Smectite/illite ratio. E. Kaolinite/illite ratio. Age determination according to the nannofossil biostratigraphy (Lohman; Martini; both this volume). Auxiliary lines emphasizing the major changes in the sediment record are arbitrary. 


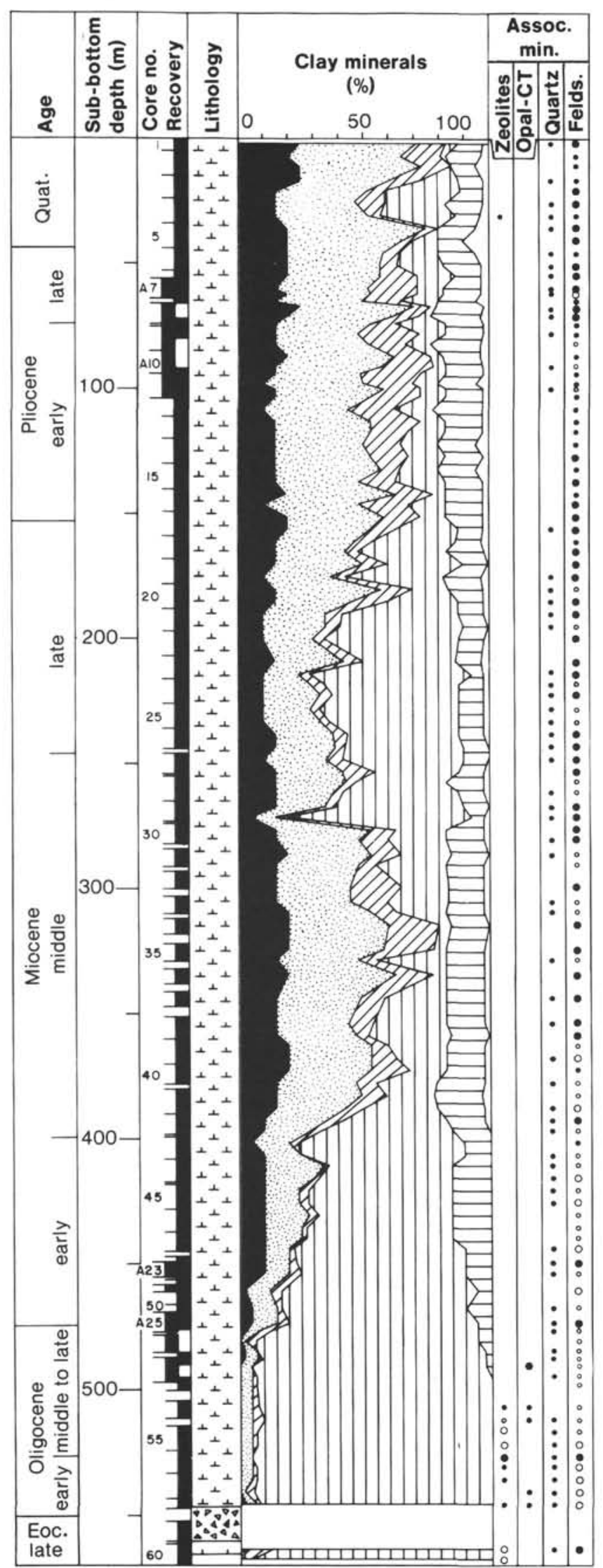

Figure 4. Site 593. Results. See Figure 2 for explanation of symbols.

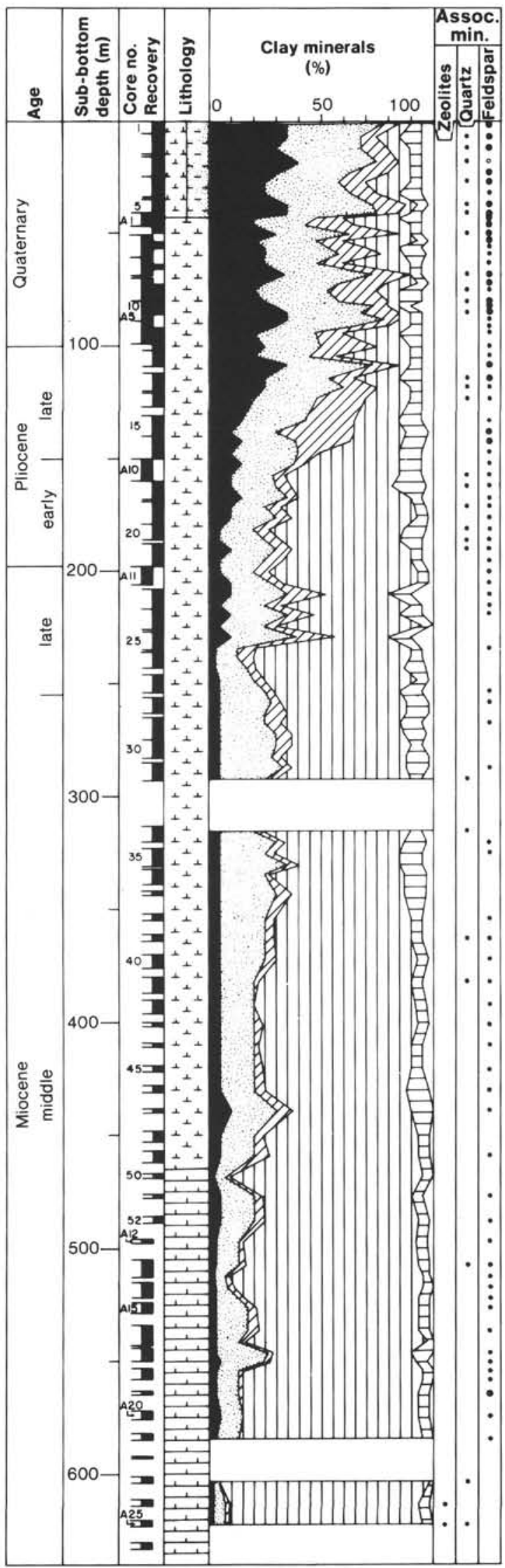

Figure 5. Site 594. Results. See Figure 2 for explanation of symbols. 
are present today over a large portion of New Zealand. Moreover, stilpnomelane, mineral characteristic of lowgrade, regionally metamorphosed terranes, is present in the sediment. Stilpnomelane is known as a widespread, abundant constituent of the schists of western Otago, in the South Island of New Zealand (Hutton, 1956; Deer et al., 1969). This mineral is present from the middle Miocene to the Pleistocene in the vicinity of New Zealand, at Site 593 on the Challenger Plateau and at Site 594 on the Chatham Rise. It also appears during the Quaternary at Site 592, on the southern Lord Howe Rise. These data suggest that the detrital supply from New Zealand had strong influence in this sector of the southwest Pacific.

The particles may have been transported by the currents which flow southward along the western coasts of New Zealand (Stanton, 1976; Ridgway, 1980) and then northward out at sea (Wyrtki, 1962). Taking into account meteorological data (Ramage, 1970), a portion of the particles could also have been transported by surface winds from northern New Zealand and by mid to high tropospheric westerly winds from Australia, toward the southern Lord Howe Rise. Rare palygorskite-like fibers are present in the Tasman Sea. Similar fibers, often associated in clusters, have been described previously in eolian dusts transported from Africa by trade winds and sampled in the Mediterranean (Robert et al., in press). During the last 15 m.y. (middle Miocene), the modes of the grain-size distribution of the terrigenous silt fraction from Site 592 are very similar to those from Sites 588 and 590 on the northern and middle Lord Howe Rise. This may indicate that the terrigenous silt at all three sites has the same source area (Dauphin, 1980; Sarnthein et al., 1982), that is, probably the Australian continent (Stein and Robert, this volume). East of New Zealand, the particles are transported by currents directed toward the northeast (Heath, 1981).

\section{Main Significance of the Clay Minerals}

Sites 592, 593, and 594 (Figs. 2-5) are subject principally to the detrital influence of New Zealand. Strong variations in the clay mineral associations are sometimes inconsistent with the climatic evolution of the Cenozoic (Kennett, 1977; Robert, 1982). Indeed, Eocene climates favored the formation of abundant smectites. Then, from the Eocene/Oligocene boundary to the Pleistocene, chlorite, illite, and irregular mixed-layer clays increased progressively (Chamley, 1979; Robert, 1982). On the southern Lord Howe Rise (Site 592), abundant illite and irregular mixed-layer clays were deposited during the late Eocene and the early Oligocene. On the Challenger Plateau and Chatham Rise, Sites 593 and 594, drilled at similar latitudes in the temperate zone, show very different abundances of illite and irregular mixed-layer clays during the middle and late Miocene. Climatic conditions strongly influenced clay mineral genesis on the Lord Howe Rise, but in the New Zealand area the data suggest that the morphology of the continental areas, driven by structural evolution, had the most important influence on the clay mineral assemblages at the DSDP sites, as in the Cape Basin of the South Atlantic (Robert, 1982).

Regions of rugged relief favor the removal of soluble ions and allow the development of soils in which chlorite and illite, then kaolinite, form. In contrast, regions with low relief, where soluble ions accumulate in the soils of poorly drained plains and sometimes in perimarine lagoons, are characterized by abundant smectites. Rifting stages or other tectonic activity, permit removal of the clay particles formed during previous periods, and the detrital supply is enriched in chlorite, illite, irregular mixed-layer clays, and kaolinite issued from the rejuvenated relief. Alternatively, the subsidence of the continental margins and the peneplanation of pre-existing relief favor the development of the poorly drained soils and perimarine lagoons where smectites accumulate (Chamley, 1979; Robert, 1982).

The abundances of clay minerals show large temporal changes which suggest that important shifts have occurred in the continental morphology, as well as in the climatic conditions and oceanic circulation in the southwest Pacific.

\section{CENOZOIC CHANGES IN DETRITAL PARTICLES OFF NEW ZEALAND}

Around New Zealand, five mineralogical units can be distinguished during the Cenozoic (Figs. 2-5).

\section{Late Eocene-Early Oligocene}

On the Challenger Plateau (Hole 593, Cores 56 to $60)$, volcanogenic turbidites were deposited, surrounded by calcareous biogenic sediments containing $85-100 \%$ smectites. When these turbidites were deposited, the calcareous biogenic sediments on the southern Lord Howe Rise (Hole 592, Cores 33 to 41) contained relatively abundant illite (5 to $20 \%$ ) and irregular mixed-layer clays (5 to $20 \%$ ), accompanied by chlorite and kaolinite (trace amounts to $5 \%$ ). Smectites, however, remained the most abundant minerals (60 to $95 \%$ ). In Cores 34 and 35, the carbonate-free silt fraction shows significant amounts of relatively coarse yellowish volcanic glass.

\section{Middle Oligocene-Late Oligocene}

During this period, a hiatus occurred on the Lord Howe Rise (Site 592), while on the Challenger Plateau (Cores 593-50 to 593-56; Cores 593A-25 to 593A-27), smectites were the dominant minerals $(95 \%)$, and were accompanied by $5 \%$ illite and trace amounts of irregular mixed-layer clays.

\section{Early Miocene}

Above the hiatus, on the southern Lord Howe Rise (Cores 592-29 to 592-33), smectites were dominant (95\%), accompanied by kaolinite ( $5 \%$ ) and illite (trace amounts). On the Challenger Plateau (Cores 593-43 to 593-50; Cores 593A-23 to 593A-25), smectites prevailed (50 to $70 \%$ ). Kaolinite (10 to $15 \%$ ), illite (10 to $15 \%$ ), chlorite (trace amounts to $10 \%$ ), and irregular mixed-layer clays (trace amounts to 5\%) were also present. 


\section{Middle Miocene-Late Miocene}

During this period on the south Lord Howe Rise (Cores 592-19 to 592-29), smectites dominated the clay fraction (35 to 100\%). They were accompanied by illite (trace amounts to $30 \%$ ), kaolinite (trace amounts to $25 \%$ ), irregular mixed-layer clays (trace amounts to $10 \%$ ), and chlorite $(0$ to $5 \%)$. Significant amounts of yellowish volcanic glass, relatively coarse, were distinguished in the carbonate-free silt fraction, in Cores 20 (10.5 m.y.), 25, and 26 (13 to 14 m.y.).

On the Challenger Plateau (Cores 593-23 to 593-42), illite dominated (10 to $45 \%$ ), associated with chlorite (5 to $20 \%$ ), kaolinite ( 5 to $20 \%$ ), and irregular mixed-layer clays (trace amounts to 20\%). Smectites remained intermittently important (5 to $80 \%$ ). Stilpnomelane appeared in trace amounts.

On the Chatham Rise, east of New Zealand (Cores 594-26 to 594-52; Cores 594A-12 to 594A-26), smectites were very abundant ( 45 to $95 \%$ ). They were accompanied by illite (trace amounts to $30 \%$ ), kaolinite (trace amounts to $10 \%$ ), chlorite (trace amounts to $10 \%$ ), and irregular mixed-layer clays (trace amounts to $5 \%$ ). Stilpnomelane (0 to $5 \%)$ was also present.

\section{Late Miocene-Pleistocene}

On the southern Lord Howe Rise (Cores 592-1 to 592-18), illite increased (5 to $40 \%$ ) and smectites decreased ( 75 to $25 \%$ ). These minerals were accompanied by kaolinite (10 to $30 \%$ ), irregular mixed-layer clays (trace amounts to $20 \%$ ), and chlorite (0 to 10\%). Trace amounts of stilpnomelane were present during Pleistocene time. The accumulation rates of the carbonate-free silt fraction show its first maxima near 10 and $6 \mathrm{~m}$.y. (late Miocene), followed by a distinct maximum near 4 m.y. (early Pliocene). The last 3.5 m.y. (late PliocenePleistocene) were characterized by a distinct coarsening of the grain size of the $>63 \mu \mathrm{m}$ fraction and the terrigenous silt fraction, and accumulation rates decreased. This change occurred at the same time also at Sites 588, 590, and 591 (Stein and Robert, this volume).

On the Challenger Plateau at this time as earlier (Cores 593-1 to 593-23; Cores 593A-7 to 593A-11), illite increased (15 to $55 \%)$ and smectites decreased $(60 \%$ to 0$)$. They were associated with chlorite (10 to $25 \%$ ), irregular mixedlayer clays (5 to $25 \%$ ), kaolinite (10 to $20 \%$ ), and stilpnomelane ( 0 to $10 \%)$.

During the same period to the east of New Zealand (Cores 594-1 to 594-25; Cores 594A-1 to 594A-11), illite also increased ( 15 to $45 \%$ ), as did chlorite ( 5 to $40 \%$ ), irregular mixed-layer clays ( $(5$ to $35 \%)$, and stilpnomelane (trace amounts to $10 \%)$; smectites $(60 \%$ to 0$)$ and kaolinite (10 to $5 \%$ ), however, decreased. During the late Pliocene, in particular, smectites decreased abruptly, from 60 to $10 \%$, and chlorite, illite and mixed-layer clays increased in the same proportions. This change in the mineralogy immediately followed increased terrigenous supply in the bulk sediment, marked by alternations of detritus-rich and detritus-poor deposits. The presence of this event at Site 594 suggests that a drastic change in the detrital supply on the Chatham Rise occurred during the late Pliocene (Site 594 site chapter, this volume).

\section{EVOLUTION OF TECTONICS AND CURRENTS IN THE NEW ZEALAND SECTOR}

The important differences in the temporal and geographical distribution of the clay minerals suggest that the New Zealand area underwent a complex evolutionary history during the Cenozoic (Fig. 6, Table 2).

\section{Late Eocene-Early Oligocene}

After the Rangitata orogenesis during the Cretaceous, New Zealand became a passive margin until Oligocene time, while active spreading separated Antarctica and Australia (Crook and Feary, 1982). However, at the end of the late Eocene, an increase in illite and irregular mixed-layer clays appeared at Site 592 on the southern Lord Howe Rise. The composition of the clay fraction points to the local formation of continuously rejuvenated relief, because kaolinite does not form abundantly in soils. The presence of a youthful relief was possibly due to a distensive stage in New Zealand. Following a change in the rotation of the plates at $40 \mathrm{~m}$.y. (Malahoff et al., 1982), a suite of faults and grabens formed in the South Island of New Zealand, especially in the region now corresponding to the Moonlight Tectonic Zone (Norris et al., 1978). At the end of the Eocene, volcanogenic turbidites were emplaced at Site 593 and volcanic glasses were deposited at Site 592. During this interval, lathed particles, sometimes associated with volcanic glass, suggest that volcanic activity also played a role in the formation of the smectites. Volcanic activity was present in New Zealand and as far north as New Caledonia (Lillie and Brothers, 1969). In other parts of New Zealand, the topography consisted of plains where smectites formed.

\section{Middle Oligocene-Late Oligocene}

During this period, smectites became dominant, indicating peneplanation of the relief, corresponding to subsidence of the continental margin. Volcanism was absent, and smectites developed in poorly drained soils or in perimarine lagoons. Smectite abundance may also indicate hot climatic conditions, with alternating periods of humidity and aridity, as in the Chad basin (Africa) today (Gac, 1979) or in the Mediterranean basin during the Messinian (Chamley et al., 1977). The observations made on the Challenger Plateau (Site 593) agree with the onshore data of Hume (1978) in northern New Zealand. During the Oligocene, the effects of subsidence were also recorded in the South Island of New Zealand (Norris et al., 1978), while tectonic quiescence induced a decrease in the volume of terrigenous particles eroded from New Zealand, and calcareous formations developed along the shore (Nelson, 1977). By this time, the presence of strong currents flowing southward across the Tasman Sea prevented deposition and eroded sediments in different regions of the southwest Pacific (Kennett, 1982), as evidenced by a hiatus on the southern Lord Howe Rise (Site 592).

\section{Early Miocene}

During the earliest Miocene, the detrital supply on the Challenger Plateau (Site 593) was marked by an increase in chlorite, illite, irregular mixed-layer clays, and 


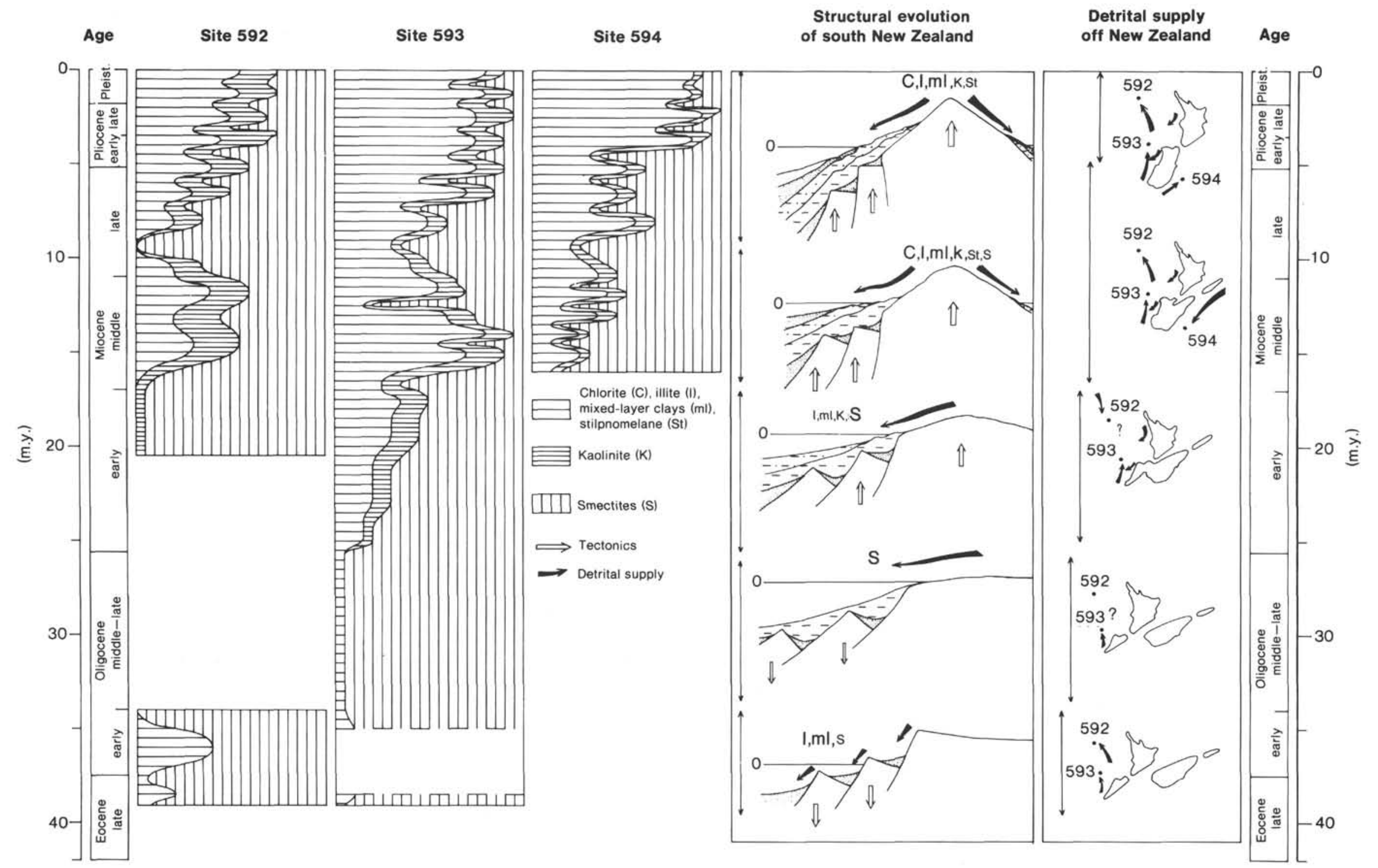

Figure 6. Evolution and significance of Cenozoic clay associations around New Zealand. Larger letters indicate more abundant minerals. 
Table 2. Chronology and interpretation of the main mineralogic events, correlated with the geologic and oceanographic history of the southwest Pacific.

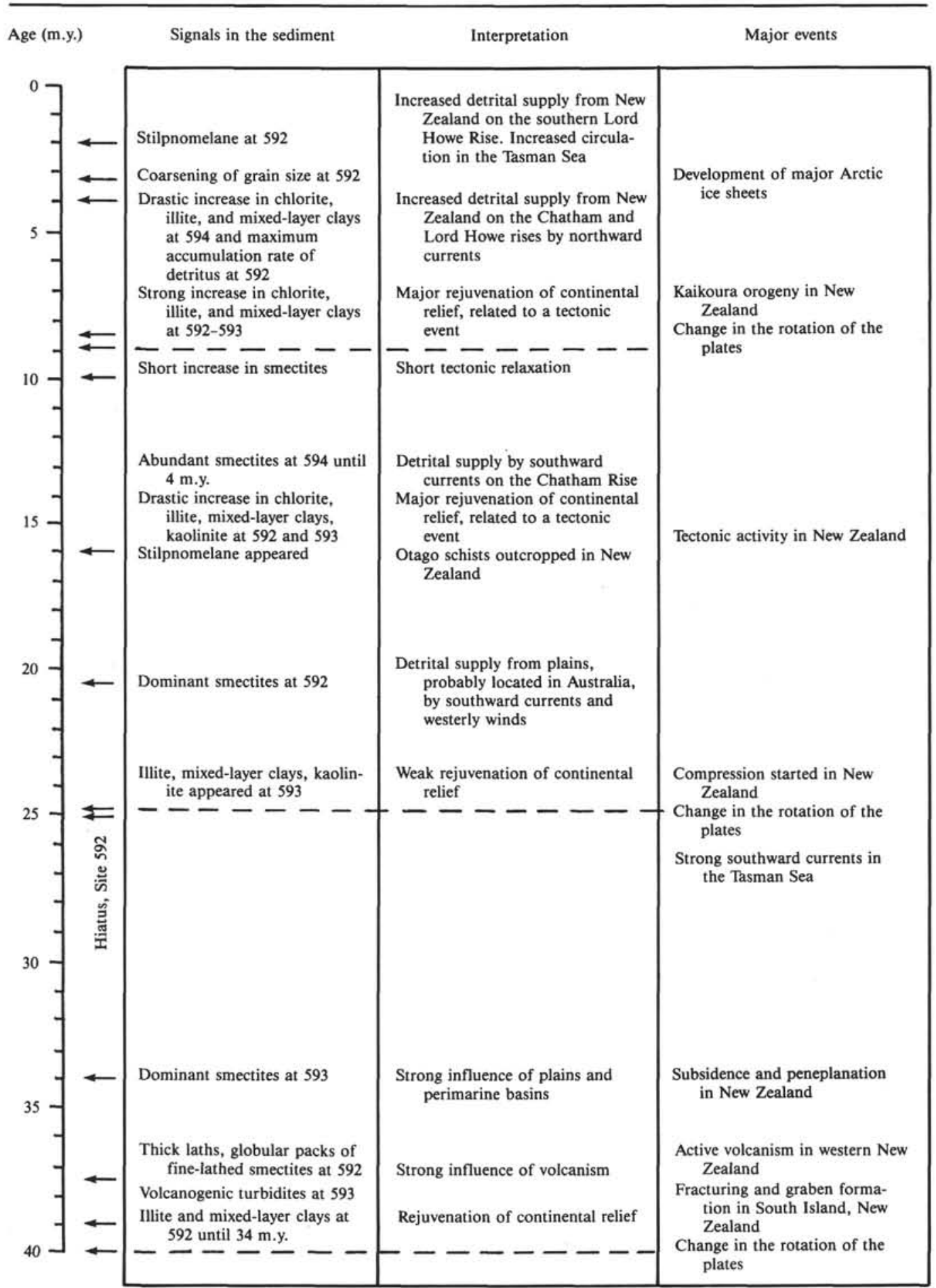

Note: major events from Crook and Feary (1982), Hume (1978), Kennett (1977, 1982), Malahoff et al. (1982), Nelson (1977), Nelson and Hume (1977), Norris et al. (1978), Stock and Molnar (1982).

kaolinite eroded from areas of high relief, probably rejuvenated by tectonism. At this time, terrigenous clays such as chlorite and illite also increased in abundance in onshore sediments (Hume, 1978). Sedimentological studies based on grain size, sedimentation rates, and miner- alogy point to tectonic activity in the North Island during the early Miocene (Nelson and Hume, 1977). The Oligocene/Miocene boundary is marked by a change in the poles of rotation of the Pacific and Indo-Australian plates (Stock and Molnar, 1982). As a consequence, a 
compressive regime began in New Zealand (Crook and Feary, 1982), resulting in regional uplift of the South Island (Norris et al., 1978).

Above the hiatus on the southern Lord Howe Rise (Site 592), the clay mineral analysis shows $95 \%$ smectites and 5\% kaolinite. This association of minerals, derived from continental regions where poorly drained plains dominate, is inconsistent with the geological history of New Zealand and with the clay mineral record on the Challenger Plateau (Site 593). Detrital supply on the southern Lord Howe Rise during the early Miocene came from a more stable and tectonically more quiescent area, probably Australia, where uplift in the eastern highlands did not begin before the end of the early Miocene (Plumb, 1979). Strong southward currents, active during the Oligocene and earliest Miocene, decreased in intensity toward $20 \mathrm{~m}$.y., when northward currents developed in the south Tasman Sea (Kennett, 1982). This change in circulation permitted the deposition of clay particles eroded from Australia and transported southward by currents (pre-East Australian Current). Additionally, eolian input from Australia by the westerlies also provided detrital particles to sediments, as on the northern and middle Lord Howe Rise (Stein and Robert, this volume).

\section{Middle Miocene-Late Miocene}

During the middle and the early late Miocene, a strong increase in the abundances of chlorite, illite, irregular mixed-layer clays, and kaolinite on the Challenger Plateau (Site 593) and the southern Lord Howe Rise (Site 592) suggests the presence of continental relief, where soils formed on slopes rejuvenated by tectonic activity in New Zealand. The detrital supply of clays from New Zealand settled on the southern Lord Howe Rise, probably because of the increased influence of northwardflowing currents in the Tasman Sea. During the middle Miocene, reverse faulting began in the South Island contemporaneously with increased continental relief and erosion, marked by coarse conglomerates on land (Norris et al., 1978). This uplift favored the outcropping and erosion of old, metamorphosed terranes containing stilpnomelane. From this time onward, stilpnomelane was present in the detrital sediments around New Zealand. On the North Island, the influence of tectonism progressively increased (Nelson and Hume, 1977). More extensive volcanic activity (Crook and Feary, 1982) led to increased abundances of smectites in the sedimentary basins located on land (Hume, 1978). This increase in abundance of smectites was not observed in Tasman Sea sediments. There, detrital supply related to tectonic activity was largely dominant, though silty volcanic glasses were present in the sediment. Similar volcanic glasses were recovered on the northern and middle Lord Howe Rise (Sites 588 and 590), where they were more frequent during the same period (Stein and Robert, this volume). They may have originated from New Zealand, transported by surface winds. They may also have been supplied from tropical regions (Melanesia, New Hebrides) by hurricanes which flow southward in the Coral and Tasman seas (Ramage, 1970). However, at the end of the period under consideration, an increased supply of smectites in the sediments points to an increased influence of plain areas or volcanic activity on the southern Lord Howe Rise.

East of New Zealand, on the Chatham Rise (Site 594), chlorite, illite, irregular mixed-layer clays, and kaolinite are present in weak abundances at this site, located close to the South Island. Fluctuations in the mineral abundances are related to tectonic pulses, as at other sites. During the middle and the late Miocene, radiolarian associations include species of tropical origin (Caulet, this volume). As a consequence, it seems probable that the clay minerals supplied by erosion of proximal areas under tectonic influence were diluted by distal supplies of smectites, brought by currents flowing southward from the central Pacific (Caulet and Robert, in press).

\section{Late Miocene-Pleistocene}

This last period began with increased abundances of chlorite, illite, irregular mixed-layer clays, and stilpnomelane. On the southern Lord Howe Rise (Site 592), this increase seems too important to be related to climatic cooling at this latitude (Robert, 1982), where presentday climatic conditions favor smectite formation (Pedro, 1968). Furthermore, the relatively high kaolinite abundances present during that time are inconsistent with a climatic interpretation of the clay mineral association at Site 592. The data suggest rather, a resurgence of tectonic activity. During the late Miocene, at about 10 m.y., a new shift in the poles of rotation of the plates induced a more important compression, at the origin of the Kaikoura Orogeny (Crook and Feary, 1982). The effects of this tectonic stage on clay minerals appear clearly on the Challenger Plateau (Site 593) between the middle late Miocene (late NN11a, Core 23) and the middle early Pliocene (NN12-NN13, Core 16). Tectonic influences reached a climax close to the Miocene/Pliocene boundary and during the early Pliocene. Mass accumulation rates also record this evolution, characterized by maxima at 10 and $6 \mathrm{~m} . \mathrm{y}$. (late Miocene), then at 4 m.y. (early Pliocene) on the southern Lord Howe Rise. These maxima were interpreted as increased inputs of terrigenous matter, with negligible content of biogenic opal (Fig. 3). These important tectonic influences correspond to the Kaikoura Orogeny. The earlier maximum is also in agreement with sedimentological data from the North Island, based on sedimentation rates and mineralogy, which point to a maximum influence of tectonism at $5 \mathrm{~m}$.y. (Nelson and Hume, 1977). Since that time, clay minerals have not shown any important change, suggesting that New Zealand had by then acquired its present morphology.

On the southern Lord Howe Rise, increased percentages of the sediment fraction $>63 \mu \mathrm{m}$ and terrigenous matter $>6 \mu \mathrm{m}$ suggest that currents exercised increased influence during the late Pliocene and the Quaternary (Fig. 3). During the Quaternary, stilpnomelane from south New Zealand appeared at Site 592, suggesting that the detrital supply from New Zealand had an increased influence on the southern Lord Howe Rise, induced by reinforced northward currents in the Tasman Sea.

On the Chatham Rise (Site 594), tectonic influence increased during the middle late Miocene, but the maxi- 
mum abundance of chlorite, illite, and irregular mixedlayer clays occurred during the late Pliocene, following the onset of the cyclic terrigenous supply (Site 594 site chapter, this volume). During the same period, radiolarian associations show replacement of tropical by antarctic species, suggesting an inversion of the surface current system east of New Zealand. As northward currents replaced southward currents, increased abundances of clay minerals from the Southern Alps were supplied to Site 594 (Caulet and Robert, in press) and climatic cycles, marked by alternating detritus-rich and detritus-poor levels (Site 594 site chapter, this volume) appeared in the sedimentary record. On the North Island, mainly during the Pleistocene, an increase in abundance of smectites occurred in the sedimentary basins close to the volcanics which developed with the initiation of the Havre TroughTaupo Graben (Hume, 1978). This increase in smectite abundance does not appear in the marine sediments recovered on the southern Lord Howe Rise, the Challenger Plateau, and the Chatham Rise, though light volcanic glass was observed in the carbonate-free silty fraction near 1.4 m.y. on the southern Lord Howe Rise. This is probably caused by preferential sedimentation toward the graben itself, and by dilution of the particles transported out of the graben into the detrital supply eroded from the New Zealand Alps.

\section{CONCLUSION}

In the New Zealand sector of the southwest Pacific, temporal variations in the clay mineral associations and grain-size distribution are mainly controlled by continental morphology, which is intimately tied to the structural evolution of the region. From the late Eocene onward, a continental margin evolves. A distensive stage occurred near the Eocene/Oligocene boundary, followed by subsidence during the Oligocene. A compressional regime began at the Oligocene/Miocene boundary and increased during the late Miocene, leading to several tectonic stages. Moreover, a comparison of the data obtained at these three sites suggests changes in oceanic circulation: the slowing of southward currents during the early Miocene, and transition from southward to northward currents in the Tasman Sea at the beginning of the middle Miocene, and east of New Zealand during the late Pliocene.

\section{ACKNOWLEDGMENTS}

Financial support for this study was provided by the Centre $\mathrm{Na}$ tional de la Recherche Scientifique (A.T.P. Géologie et Géophysique des Océans) and the Deutsche Forschungsgemeinschaft. We should like to express our thanks to T. Allert, J. P. Ripert, F. Sirocko, R. Spielhagen, and M. Stransky for technical assistance. We are grateful to $\mathrm{H}$. Chamley, J. P. Kennett, C. S. Nelson, M. Sarnthein, H. Zimmerman, and an anonymous colleague who offered aid and constructive comments during the genesis of this paper or during its review.

\section{REFERENCES}

Caulet, J. P., and Robert, C., in press. Reconstruction of Neogene paleoenvironments at Site 594 (Chatham Rise, Leg 90) from radiolarian and clay mineral study. Paleogeogr., Paleoclimatol., Paleocol.

Chamley, H., 1979. North Atlantic clay sedimentation and paleoenvironment since the late Jurassic. In Talwani, M., Hay, W., and Ryan, W. B. F. (Eds.), Deep Drilling Results in the Atlantic Ocean:
Continental Margins and Paleoenvironments: Washington (Am. Geophys. Union), pp. 342-360.

1980. Clay sedimentation and paleoenvironment in the area of the Daito Ridge (Northwest Philippine Sea) since the early Eocene. In Klein, G. de V., Kobayashi, K., et al., Init. Repts. DSDP, 58: Washington (U.S. Govt. Printing Office), 683-693.

Chamley, H., and Bonnot-Courtois, C., 1981. Argiles authigènes et terrigènes de l'Atlantique et du Pacifique N.W. (legs 11 et 58 DSDP): apport des terres rares. Oceanol. Acta, 4(2):229-238.

Chamley, H., Giroud d'Argoud, G., and Robert, C., 1977. Genèse des smectites messiniennes de Sicile. Implications paléoclimatiques. Geol. Medit., 4(4):371-378.

Chamley, H., Maillot, H., Duée, G., and Robert, C., 1984. Paleoenvironmental history of the Walvis Ridge at the Cretaceous-Tertiary transition, from mineralogical and geochemical investigations. In Moore, T. C., Rabinowitz, P. D., et al., Init. Repts. DSDP, 74: Washington (U.S. Govt. Printing Office), 685-695.

Crook, K. A. W., and Feary, D. A., 1982. Development of New Zealand according to the fore-arc model of crustal evolution. Tectonophysics, 87:65-107.

Dauphin, J. P., 1980. Size distribution of chemically extracted quartz used to characterize fine-grained sediments. J. Sed. Petrol., 50: 205-214.

Deer, W. A., Howie, R. A., and Züssmann, J., 1969. An Introduction to the Rock-forming Minerals: London (Longmans).

Gac, J. Y., 1979. Géochimie du bassin du lac Tchad. Bilan de l'altération, de l'érosion et de la sédimentation [D. Sci. dissert.]. University of Strasbourg.

Heath, R. A., 1981. Oceanic fronts around southern New Zealand. Deep-Sea Res., 28A(6):547-560.

Hoffert, M., 1980. Les argiles rouges des grands fonds dans le Pacifique Centre-Est. Authigenèse, transport, diagenèse [D. Sci. dissert.]. University of Strasbourg.

Holtzapffel, T., Bonnot-Courtois, C., Chamley, H., and Clauer, N., in press. Héritage et diagenèse dans la constitution des smectites nord-atlantiques (Crétacé-Paléogène). Bull. Soc. Géol. France.

Hume, T. M., 1978. Clay petrology of Mesozoic to recent sediments of central western North Island, New Zealand [Ph. D. dissert.]. Waikato University, Hamilton, N.Z.

Hutton, C. O., 1956. Further data on the stilpnomelane mineral group. Am. Mineral., 41:608-615.

Kennett, J. P., 1977. Cenozoic evolution of Antarctic glaciation, the circum-Antarctic Ocean, and their impact on global paleoceanography. J. Geophys. Res., 82(27):3843-3860.

1982. Marine Geology: Englewood Cliffs (Prentice-Hall).

Lillie, A. R., and Brothers, R. N., 1970. The geology of New Caledonia. N.Z.J. Geol. Geophys., 13(1):145-183.

Malahoff, A., Feden, R. H., and Fleming, H. S., 1982. Magnetic anomalies and tectonic fabric of marginal basins north of New Zealand. J. Geophys. Res., 87(B5):4109-4125.

Millot, G., 1964. Géologie des argiles: Paris (Masson).

Nelson, C. S., 1977. Geological History of New Zealand. Auckland Geogr. Teachers Group, 4.

Nelson, C. S., and Hume, T. M., 1977. Relative intensity of tectonic events revealed by the Tertiary sedimentary record in the North Wanganui basin and adjacent areas, New Zealand. N.Z.J. Geol. Geophys., 20(2):369-392.

Norris, R. J., Carter, R. M., and Turnbull, I. M., 1978.Cainozoic sedimentation in basins adjacent to a major continental transform boundary in southern New Zealand. J. Geol. Soc. London, 135: 191-205.

Pedro, G., 1968. Distribution des principaux types d'altération chimique à la surface du globe. Rev. Géogr. Phys. Géol. Dyn., 10(5): $457-470$.

Plumb, K. A., 1979. The tectonic evolution of Australia. Earth Sci. Rev., 14:205-249.

Ramage, C. S., 1970. Meteorology of the South Pacific, tropical and middle latitudes. In Wooster, W. S., (Ed.), Scientific Exploration of the Southwest Pacific: Washington (National Academy of Sciences), pp. 32-60.

Ridgway, N. M., 1980. Hydrological conditions and circulation off the West coast of the North Island, New Zealand. N.Z.J. Marine Freshwater Res., 14(2):155-167. 
Robert, C., 1982. Modalité de la sédimentation argileuse en relation avec l'histoire géologique de l'Atlantique Sud [D. Sci. dissert.]. University of Aix-Marseille 2.

Robert, C., Gauthier, A., and Chamley, H., in press. Origine autochtone et allochtone des argiles récentes de haute altitude en Corse. Rev. Géol. Médit.

Sarnthein, M., Thiede, J., Pflaumann, U., Erlenkeuser, H., Fuetterer, D., Koopmann, B., Lange, H., and Seibold, E., 1982. Atmospheric and oceanic circulation patterns off Northwest Africa during the past $\mathbf{2 5}$ million years. In von Rad, U., Hinz, K., Sarnthein, M., and Seibold, E. (Eds.), Geology of the Northwest African Continental Margin: Berlin (Springer-Verlag), pp. 545-604.

Stanton, B. R., 1976. Circulation and hydrology off the west coast of the South Island, New Zealand. N.Z.J. Marine Freshwater Res., 10(3):445-467.

Stein, R., 1984. Zur neogenen Klimaentwicklung in Nordwest Afrika und Paläo-Ozeanographie im Nordost-Atlantik: Ergebnisse von
DSDP Sites 141, 366, 397 und 544B. Ber. Rep., Geol. Paläontol. Inst. Univ. Kiel, 4. [Ph. D. dissert.]

Stock, J., and Molnar, P., 1982. Uncertainties in the relative positions of the Australia, Antarctica, Lord Howe and Pacific plates since the Late Cretaceous. J. Geophys. Res., 87(B6):4697-4714.

Thiede, J., Suess, E., and Mueller, P. J., 1982. Late Quaternary fluxes of major sedimentary components to the seafloor at the Northwest African continental slope. In von Rad, U., Hinz, K., Sarnthein, M., and Seibold, E. (Eds.), Geology of the Northwest African Continental Margin: Berlin (Springer-Verlag), pp. 605-631.

Wyrtki, K., 1962. Geopotential topographies and associated circulation in the western South Pacific Ocean. Aust. J. Marine Freshwater Res., 13(2):89-105.

Date of Initial Receipt: 28 June 1984

Date of Acceptance: 10 May 1985 


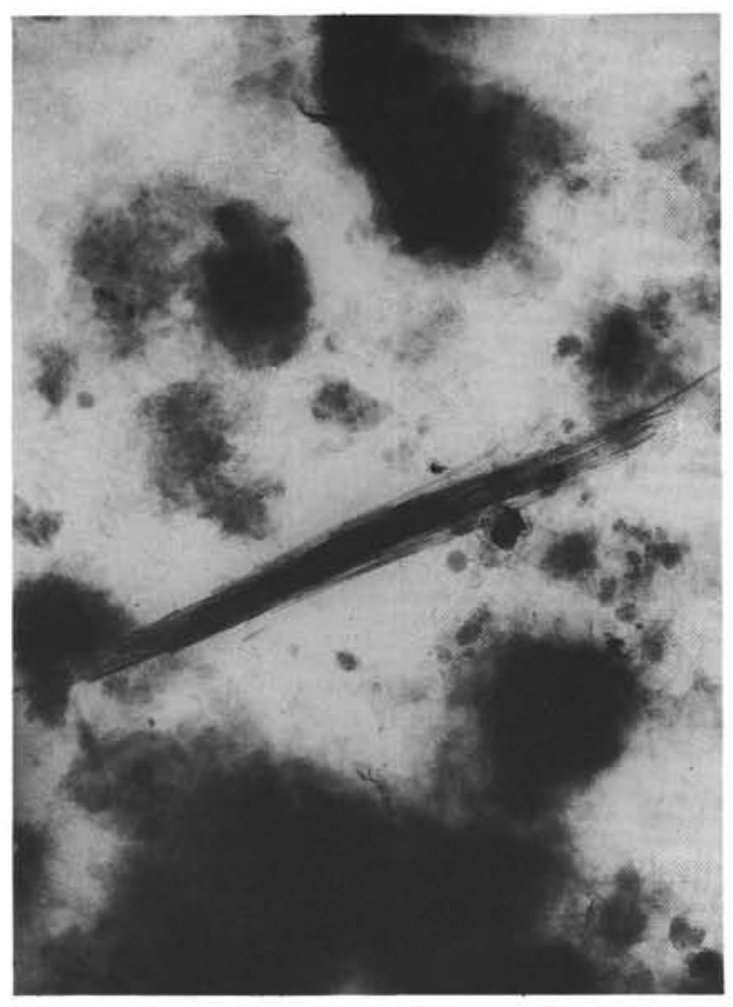

1

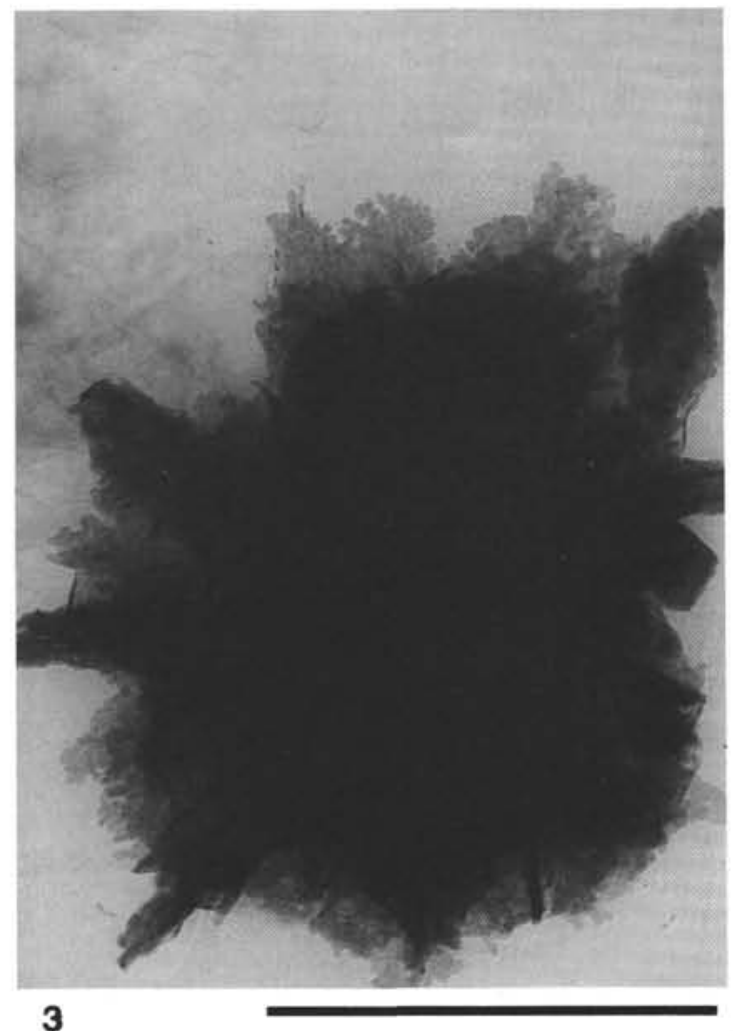

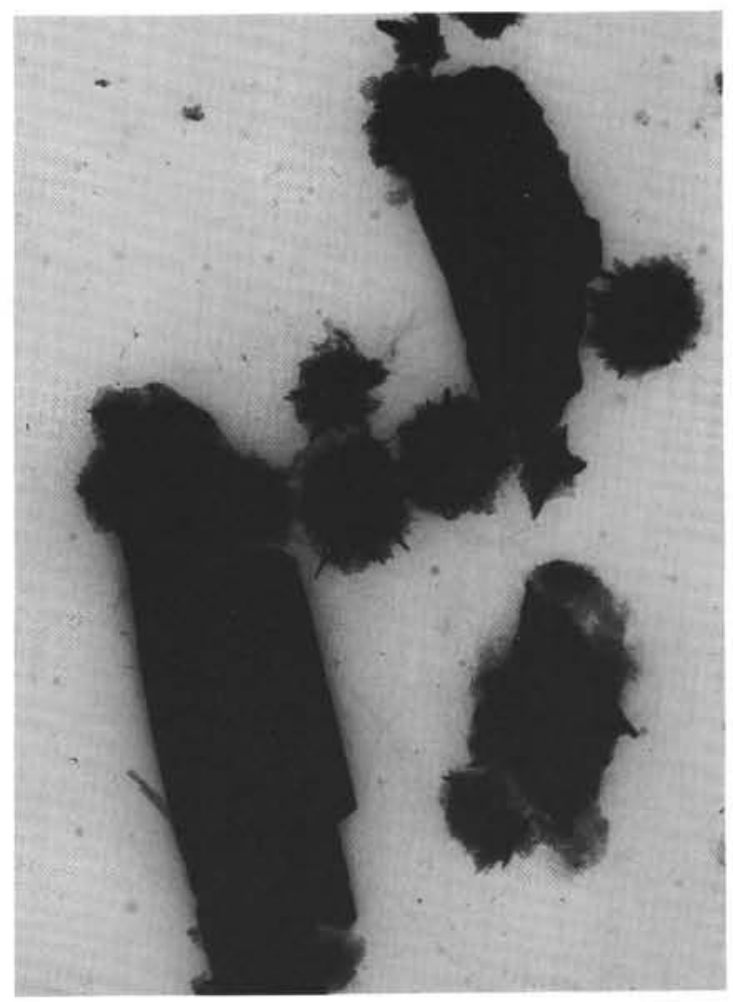

2

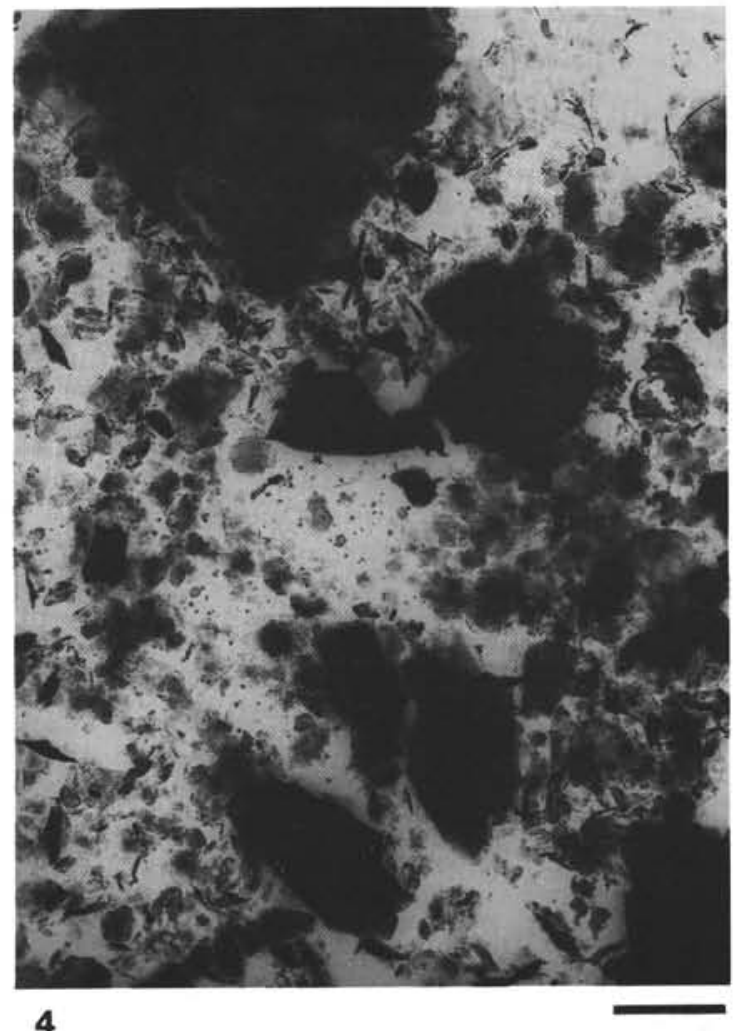

Plate 1. Electromicrographs. (Scale bar $=1 \mu \mathrm{m}$.) 1. Sample 592-19-2, $50 \mathrm{~cm}$, late Miocene; association of palygorskite-like fibers, abundant fleecy particles, and very fine laths in clay fraction containing up to $100 \%$ smectites. 2-3. Sample $592-41-2,50 \mathrm{~cm}$, late Eocene, (2) thick-lathed particles and globular packs of fine laths, dominant in sample containing 85\% smectites; (3) globular pack of fine laths. 4. Sample 593-3-2, $50 \mathrm{~cm}$, Quaternary; Fleecy particles, particles with sharp outlines, and rare hexagons in clay fraction containing $15 \%$ smectites, $10 \%$ irregular mixed-layer clays, $25 \%$ chlorite, $40 \%$ illite, and $10 \%$ kaolinite. 


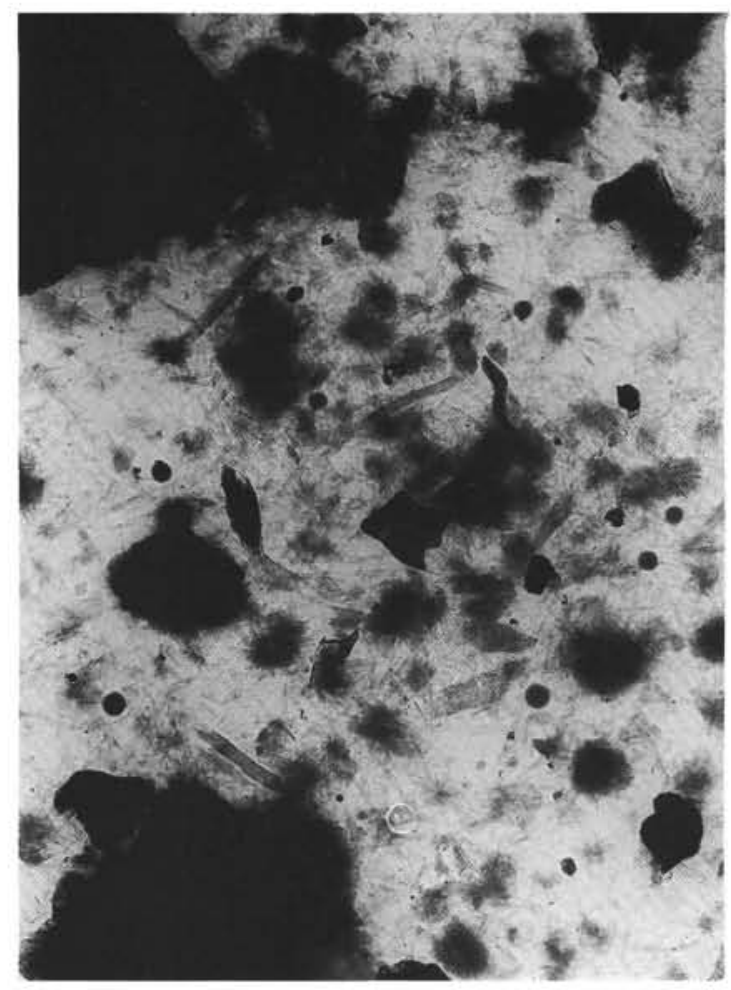

1

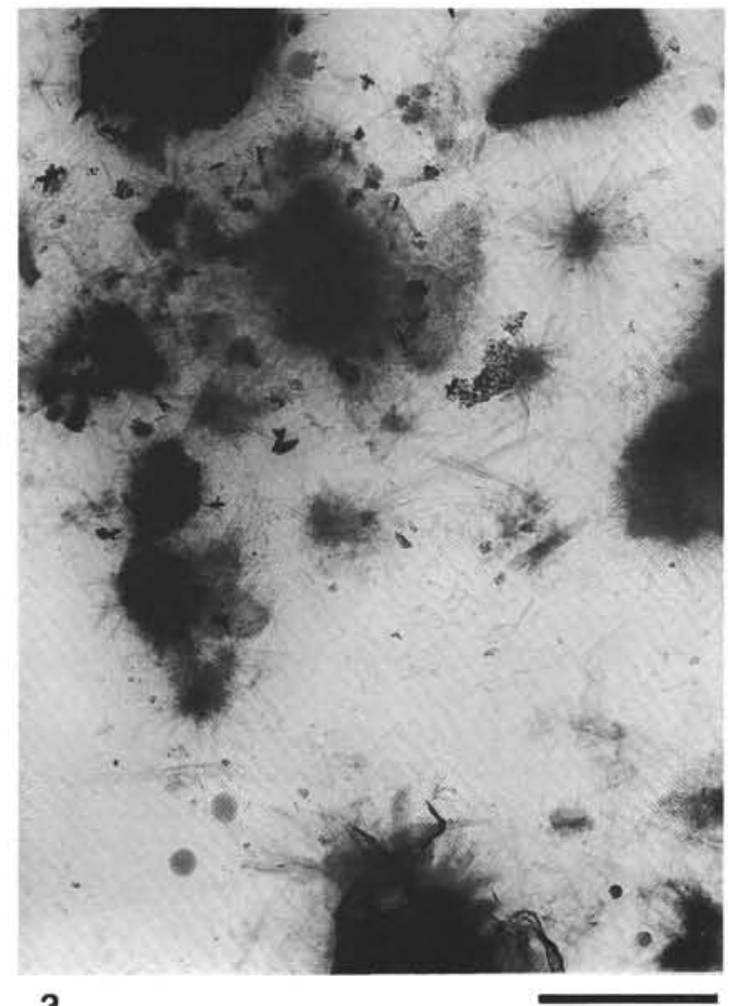

3

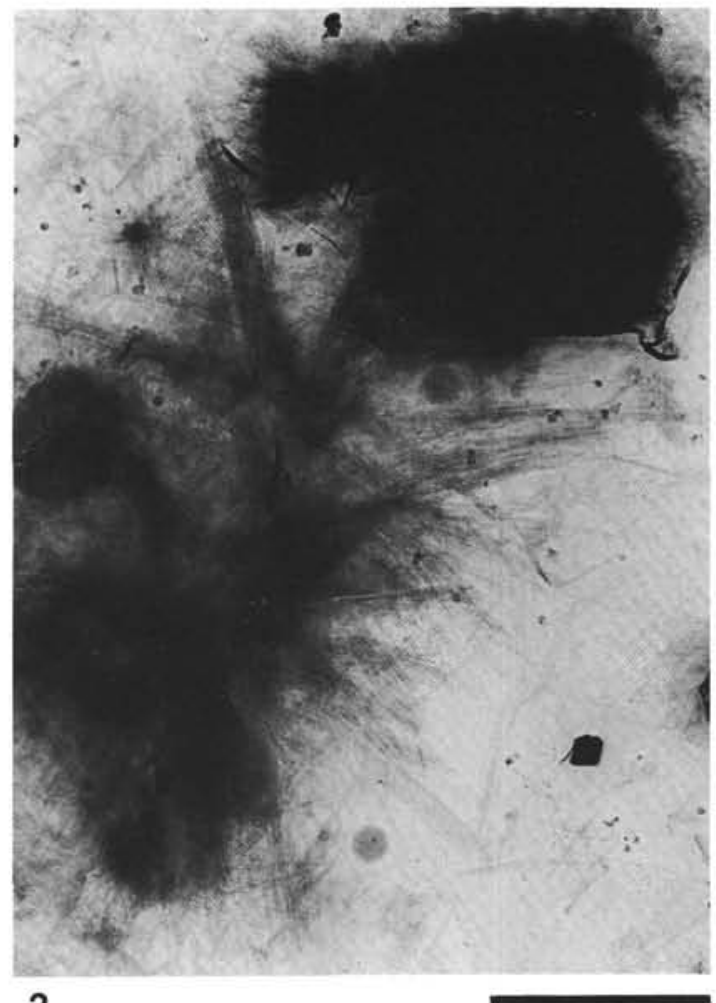

2

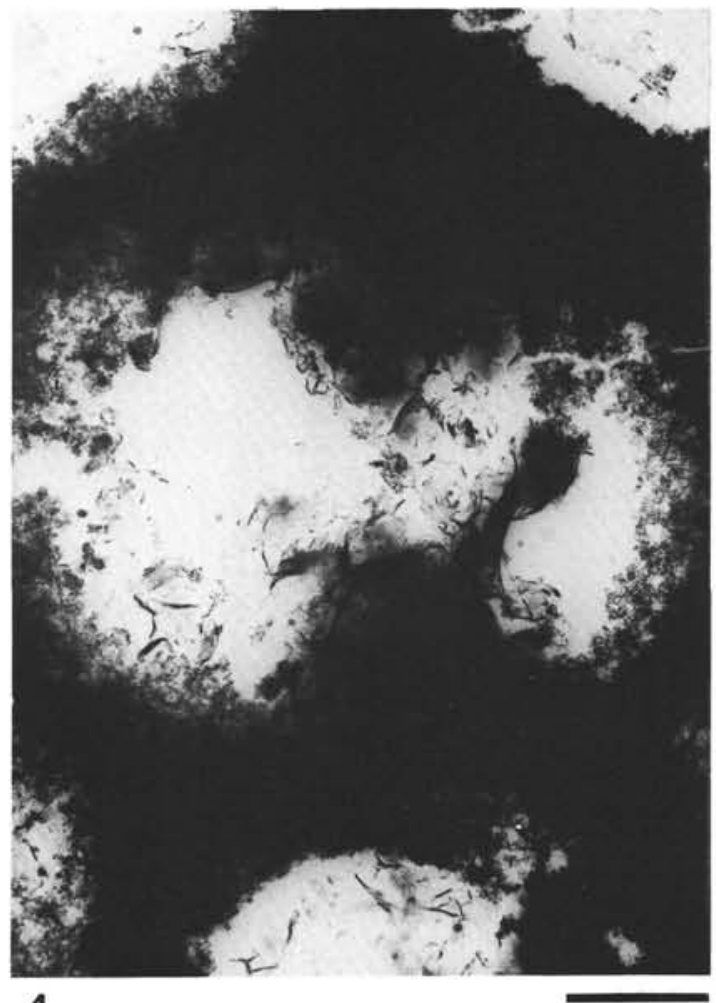

4

Plate 2. Electromicrographs. (Scale bar $=1 \mu \mathrm{m}$.) 1. Sample 593-55-2, $50 \mathrm{~cm}$, middle to late Oligocene; very fine laths, dispersed in the background or in the vicinity of fleecy particles, in clay fraction containing $95 \%$ smectites associated with $5 \%$ illite. 2 . Sample $593-58-2,50 \mathrm{~cm}$, early Oligocene; very fine laths associated in geometrical figures with $60^{\circ}$ angles, in a clay fraction containing $95 \%$ smectites associated with $5 \%$ illite. 3-4. Sample 594-26-2, $60 \mathrm{~cm}$, middle to late Miocene, (3) very fine laths growing at the periphery of big particles (probably illite), or grouped in urchins, in clay fraction containing $75 \%$ smectites associated with $10 \%$ illite, $5 \%$ irregular mixed-layer clays, and $5 \%$ kaolinite; (4) small tufts of fibers, present at the periphery and in badly preserved diatom frustules. 